\title{
Cytomorphological Studies of Trigonella foenum-graecum Autotetraploids in Three $\left(C_{1}, C_{2}, C_{3}\right)$ Generation
}

\author{
I. D. Arya ${ }^{1}$, S. Rama Rao ${ }^{2}$ and S. N. Raina ${ }^{2}$
}

Accepted August 5, 1987

Successful induction of polyploidy using colchicine is a well established phenomenon and still remains a potential cytological technique to induce numerical variations in plants. Since the discovery of Blakslee and Avery in 1937 about the chromosome doubling property of colchicine, enormous number of papers have been published on colchicine induced polyploidy. However, this technique was found to be more promising in popular ornamentals and vegetatively propagated plants. But, for some unknown reasons, induction of polyploidy in legumes was found rather difficult. A review of literature reveals that very few reports on successful induction of polyploidy in legumes (Sen and Chedda 1958, Biswas and Bhattacharya 1971, Singh and Roy 1971, Gupta and Gupta 1975, 1976, Raghuvanshi and Singh 1977, Singh and Gopal 1979, Srivastav and Raina 1982) are available in comparison to large number of reports on popular ornamentals Jalil et al. 1974, Arora 1975, Zadoo et al. 1975, Srivastav and Raina 1981, Rao et al. 1982).

Trigonella foenum-graecum (commonly known as "Methi" or "Fenugreek") of family Leguminosae and subfamily Papilionaceae, is extensively grown in tropical and subtropical regions of India for its vegetable value and seeds which are medicinally important. The present study was undertaken in a view to study the cytomorphological features of $T$. foenumgraecum polyploids in successive generations and to explore the possibility of evolving a high yielding variety in terms of vegetable value and improved seed-set.

\section{Material and methods}

Seeds of $T$. foenum-graecum used for colchicinization were obtained from Central Arid Zone Research Institute, Jodhpur.

For colchicinization three methods viz. seed treatment, cotton-swab and cotyledonary leaves immersion methods were tried. The treatment was carried out for 12 or $18 \mathrm{hrs}$ spread over 2 or 3 days with $0.15 \%$ colchicine (Sigma). For meiotic analysis buds were collected and fixed in iron acetic-alcohol overnight. Anthers stained in leucobasic-fuchsin were squashed in $1 \%$ aceto-carmine. Microphotographs were taken from temporary preparations.

\section{Observations}

Of the all the three methods employed, successful induction of polyploidy was achieved mainly by cotton swab method and partially by cotyledonary leaves immersion method (Table 1). Seed germinated after the treatment. Out of seventy seedlings treated by cotton-swab method with $0.15 \%$ colchicine for 12 or 18 hrs equally spread over three days, six were cytologically confirmed as autotetraploids. Only one out of 22 seedlings treated for $10 \mathrm{hrs}$ by cotyledonary leaves immersion method was found to be autotetraploid on cytological analysis.

Swelling of the apical region of the seedlings was the immediate effect of colchinization,

\footnotetext{
${ }^{1}$ Department of Botany, University of Rajasthan, Jaipur-302004, India (Address for communication).

2 Department of Botany, University of Delhi, Delhi-110007, India.
} 
that was observed. In the expected autotetraploids the growth rate was drastically reduced in comparison to their diploids and the flowering was delayed by 2-3 weeks in the colchiploids.

\section{Morphology, Cell Size and Growth Rate}

A comparative morphological data of diploid and autotetraploids $\left(\mathrm{C}_{0}, \mathrm{C}_{1}, \mathrm{C}_{2}\right.$ and $\left.\mathrm{C}_{3}\right)$ have been summarized in Table 2. Gigantism, a common feature exhibited by all the synthesized autotetraploids, is traced to increase in the cell size. This was reflected in significant

Table 1. Efficiency of colchicine $(0.15 \%)$ in inducing polyploidy by seed treatment, cottonswab and cotyledonary leaves immerison methods

\begin{tabular}{ccccccc}
\hline \hline Method & $\begin{array}{c}\text { No. of } \\
\text { days }\end{array}$ & $\begin{array}{c}\text { Duration of } \\
\text { treatment } \\
\text { (in hours) }\end{array}$ & $\begin{array}{c}\text { No. of seeds/ } \\
\text { seedlings } \\
\text { treated }\end{array}$ & $\begin{array}{c}\text { No. of } \\
\text { seedlings } \\
\text { survived }\end{array}$ & $\begin{array}{c}\text { No. of } \\
\text { colchi- } \\
\text { tetraploids }\end{array}$ & $\begin{array}{c}\text { Percentage } \\
\text { colchi- } \\
\text { tetraploids }\end{array}$ \\
\hline Seedtreatment method & 1 & 10 & 50 & - & - & - \\
Cotton-swab method & 3 & 18 & 50 & 39 & 4 & 12.90 \\
Cotyledonary leaves & 3 & 12 & 20 & 16 & 2 & 12.5 \\
immersion method & 1 & 10 & 22 & 16 & 1 & 6.25 \\
\hline
\end{tabular}

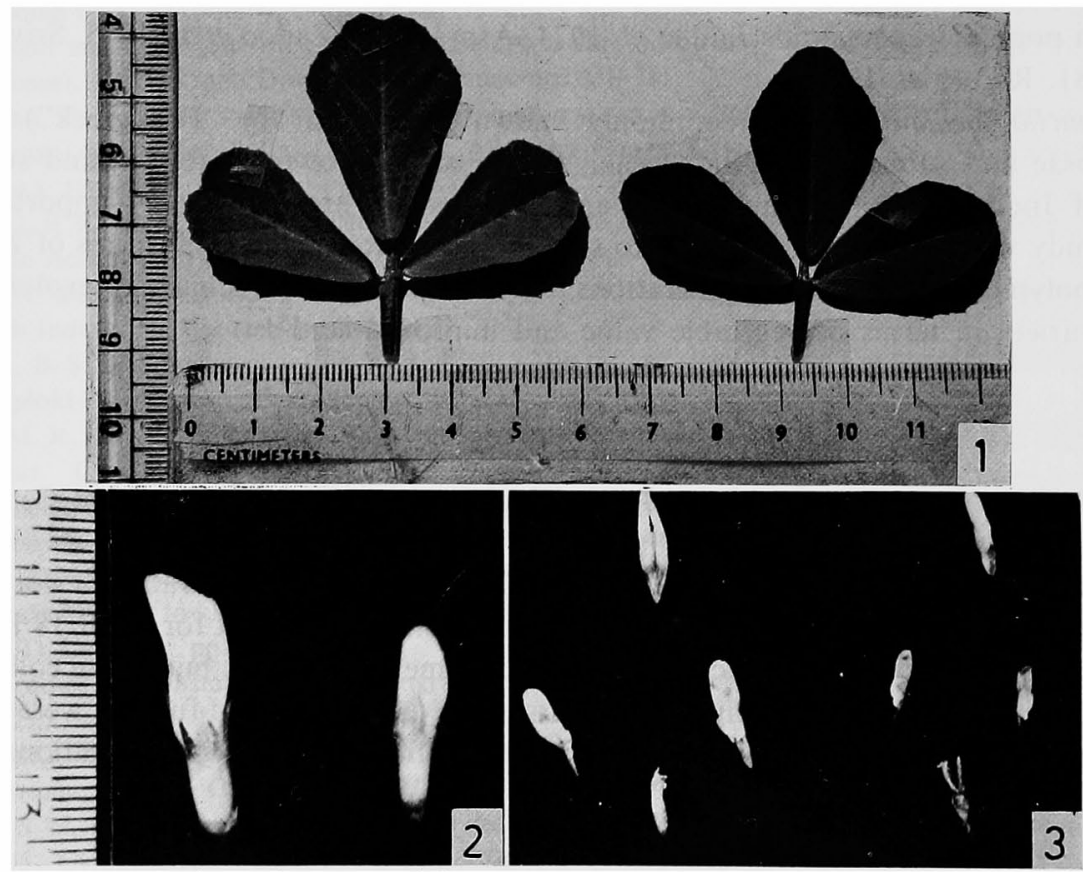

Figs. 1-3. Comparison of autotetraploid $\left(\mathrm{C}_{0}\right)$ and diploid $T$. foenum-graecum. Tetraploid (left) and diploid (right) leaves (Fig. 1), flowers (Fig. 2) and floral parts (Fig. 3).

increase of the size of stomata and pollen grains. Plant height was reduced by 24.75 per cent. However, in subsequent generations the height increased and attained near normalcy in $\mathrm{C}_{3}$ generation. Other parameters such as length and breadth of leaflets, stem thickness, size of flower etc. (Figs. 1-3) had pronounced effect after colchicine treatment. But some characters like number of seeds per plant, length of pod etc. have shown a sharp decline in number and size. But all the synthesized autotetraploids showed enhancement of their vegetative growth as expressed by increased number of branches (Table 2, Fig. 16), thick light green and bigger size leaves (less amount of leaf chlorophylls, Table 2), and of thick stem. 


\section{Cytology}

The most common situation in the diploid was 8 II (Fig. 4, Table 3). However, some cells had 0-2 univalents. The average number of associations per cell was $7.8 \mathrm{II}+0.36 \mathrm{I}$. The number of chiasmata per cell ranged from 9-16 and the mean number was 12.81 out of which 10.81 were terminalized giving terminalization coefficient as 0.84 .

Cotton-swab method was found more useful for successful induction of polyploidy, though one autotetraploid was isolated from the plants treated by cotyledonary leaves immersion method (Table 1). All the six synthesized autotetraploids $\left(C_{0}\right)$ were characterized by the presence of a mixture of quadrivalents, trivalents, bivalents and univalents. However, the average bivalent number was higher in the colchiploids. The average number of associations per cell was $0.55 \mathrm{IV}+0.44 \mathrm{III}+13.77 \mathrm{II}+0.88 \mathrm{I}$, range being $0-2,0-2,10-16$ and $0-4$ respectively (Fig. 7, Table 3). The quadrivalents were either ring or chain type. Out of 40 cells analysed $32(80 \%)$ had quadrivalents and $21(52.5 \%)$ had trivalents. Number of chiasmata ranged from $18-26$, mean being 22.77 out of which 18.80 were terminalized giving

Table 2. Morphological features of diploids and corresponding tetraploids

\begin{tabular}{|c|c|c|c|c|c|}
\hline & $2 \mathrm{x}$ & $\mathrm{C}_{0}$ & $\mathrm{C}_{1}$ & $\mathrm{C}_{2}$ & $\mathrm{C}_{3}$ \\
\hline Germination (\%) & 98.00 & - & 83.8 & 88.4 & 91.3 \\
\hline Height of the plant $(\mathrm{cm})$ & 40.18 & 30.12 & 38.72 & 39.01 & 40.21 \\
\hline Number of branches/plant & 5 & 2 & 4 & 8 & 8 \\
\hline Leaf texture & Thin & Thick & Thick & Thick & Thick \\
\hline Length of odd leaflet $(\mathrm{cm})$ & 2.67 & 2.94 & 3.32 & 3.12 & 3.20 \\
\hline Breadth of odd leaflet $(\mathrm{cm})$ & 1.82 & 1.85 & 2.39 & 2.45 & 2.45 \\
\hline Number of stomata/unit area & 7 & 4 & 4 & 5 & 5 \\
\hline Length of stomata $(\mu)$ & 31.04 & 35.72 & 34.01 & 33.98 & 34.01 \\
\hline Breadth of stomata $(\mu)$ & 23.71 & 22.45 & 20.14 & 21.58 & 21.64 \\
\hline Pollen stainability $(\%)$ & 92.67 & 67.10 & 71.22 & 76.31 & 79.01 \\
\hline Length of pod $(\mathrm{cm})$ & 10.05 & 4.10 & 4.81 & 4.72 & 5.52 \\
\hline Seed/Pod & 15.51 & 1.66 & 2.18 & 2.50 & 3.02 \\
\hline $\begin{array}{l}\text { Total leaf chlorophyll (mg/gm } \\
\text { fresh wt.) }\end{array}$ & 1.641 & - & - & 1.445 & 1.509 \\
\hline $\begin{array}{l}\text { Leaf chlorophyll a (mg/gm } \\
\text { fresh wt.) }\end{array}$ & 1.268 & - & - & 1.140 & 1.147 \\
\hline $\begin{array}{l}\text { Leaf chlorophyll b (mg/gm } \\
\text { fresh wt.) }\end{array}$ & .3737 & - & - & .36 & .3624 \\
\hline $\begin{array}{l}\text { Total leaf protenins }(\mathrm{mg} / \mathrm{gm} \\
\text { fresh wt.) }\end{array}$ & 24.00 & - & - & 26.00 & 26.00 \\
\hline
\end{tabular}

terminalization coefficient of 0.82 (Table 3). At anaphase I, 11 out of 25 cells $(44.0 \%)$ had equal (16:16) distribution of chromosomes (Fig. 10) followed by 15:17, 14:18, 13:19 in 6, 3 and 2 cells, respectively (Table 4). One cell (4\%) each had 14:17 and 15:16 distribution with one univalent lagging behind and another one cell $(4 \%)$ had $14: 16$ with one bivalent lagging behind (Fig. 10, Table 4).

The synthesized colchitetraploids $\left(C_{0}\right)$ were analysed in further three generations $\left(C_{1}, C_{2}\right.$, $\mathrm{C}_{3}$ ). In $\mathrm{C}_{1}$ plants no significant increase/decrease of quadrivalents, bivalents and univalents average was observed while there is a notable decline in the trivalent average from 0.44 to 0.31 per cell (Table 3 ). The average number of associations per cell in $\mathrm{C}_{1}$ plants was $0.55 \mathrm{IV}+$ $0.31 \mathrm{III}+13.52 \mathrm{II}+0.82 \mathrm{I}$, range being $0-3,0-1,8-14$ and $0-4$ respectively (Fig. 8). Number of chiasmata ranged from 19-29, mean being 23.85 out of which 20.34 were terminalized giving terminalization coefficient of 0.85 (Table 3). At anaphase I majority of the cells $(57.1 \%)$ had equal (16: 16) distribution of chromosomes (Fig. 11). The remaining cells had 15: $17(22.8 \%)$, 14: $18(5.7 \%), 13: 19(2.8 \%)$ distribution of chromosomes. However, 2 cells $(5.7 \%)$ showed 
the presence of 1 lagging univalent and two cells $(2.8 \%)$ had 1 lagging bivalent (Table 4).

In $\mathrm{C}_{2}$ generation the quadrivalent average was higher in comparison to both $\mathrm{C}_{0}$ and $\mathrm{C}_{1}$ plants (Fig. 9, Table 3), while the trivalent average had shown a significant further decrease

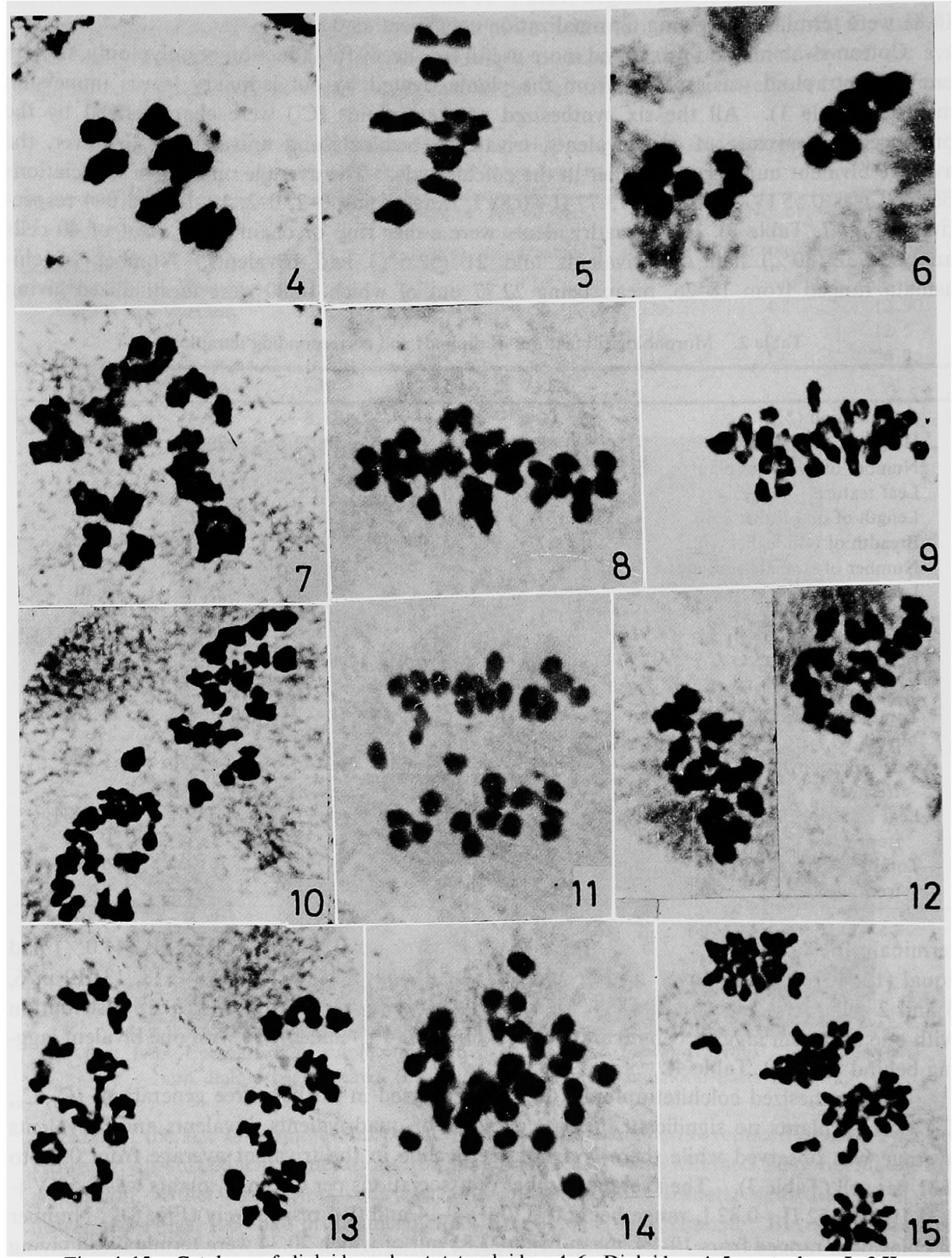

Figs. 4-15. Cytology of diploids and autotetraploids. 4-6: Diploids. 4-5, metaphase I, 8 II. 6, anaphase I, 8: 8. 7-15: Autotetraploids $\left(C_{0}, C_{1}, C_{2}, C_{3}\right)$. 7-9, metaphase I. 7, $3 \mathrm{IV}+8 \mathrm{II}+$ 4 I. 8, 16 II. $9,1 \mathrm{IV}+2 \mathrm{III}+10 \mathrm{II}+2$ I. 10-14, anaphase I. 10, 16:16. 11-13, 17: 15. 14, anaphase I showing late disjunction. 15 , anaphase II showing laggards. 


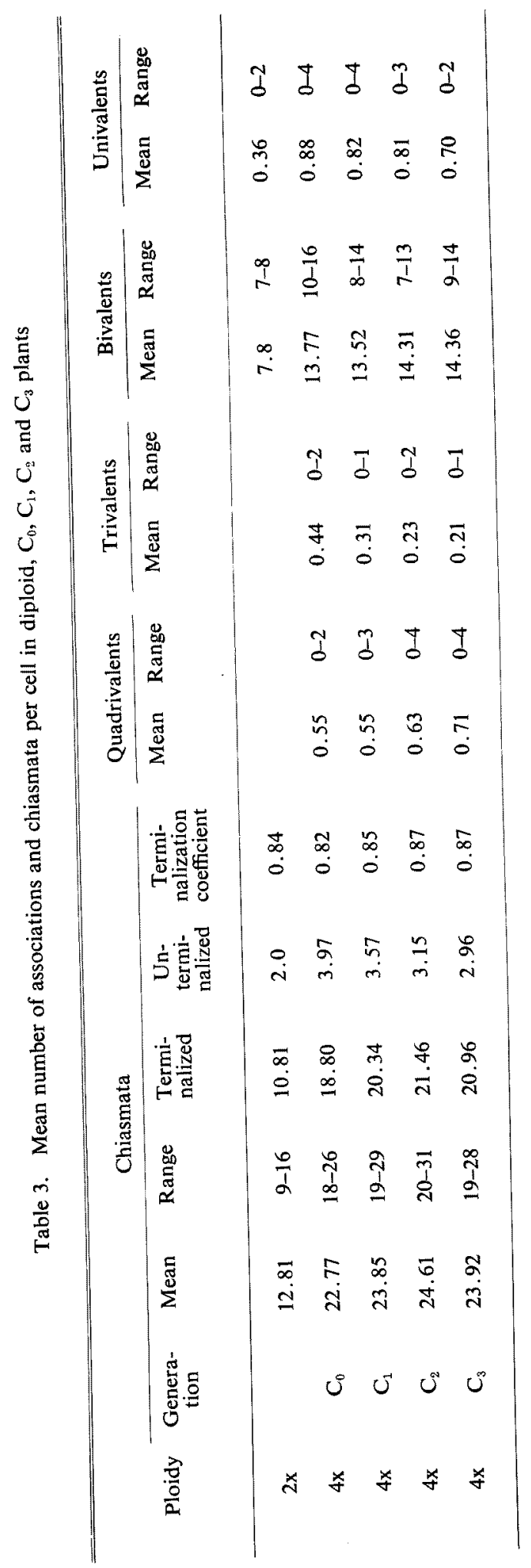


from 0.31 to 0.23 per cell. The average number of associations was $0.63 \mathrm{IV}+0.23 \mathrm{III}+14.31$ II $+0.81 \mathrm{I}$, range being $0-4,0-2,7-13$ and $0-3$ respectively. The number of chiasmata per cell ranged from $20-31$ and the mean was 24.61 out of which 21.46 were terminalized giving

Table 4. Anaphase I distribution of chromosomes

\begin{tabular}{cclcc}
\hline \hline Generation & $\begin{array}{c}\text { No. of cells } \\
\text { analysed }\end{array}$ & $\begin{array}{l}\text { Chromosome } \\
\text { distribution }\end{array}$ & No. of cells & Percentage \\
\hline $\mathrm{C}_{0}$ & 25 & $16: 16$ & 11 & 44.0 \\
& $15: 17$ & 6 & 24.0 \\
& $14: 18$ & 3 & 12.0 \\
& $13: 19$ & 2 & 8.0 \\
& & $14: 1 \mathrm{U}^{+}: 17$ & 1 & 4.0 \\
$\mathrm{C}_{1}$ & $15: 1 \mathrm{U}: 16$ & 1 & 4.0 \\
& & $14: 1 \mathrm{~B}^{++}: 16$ & 1 & 4.0 \\
& 35 & $16: 16$ & 20 & 57.1 \\
& & $15: 17$ & 8 & 22.8 \\
& & $14: 18$ & 2 & 5.7 \\
$\mathrm{C}_{2}$ & $13: 19$ & 1 & 2.8 \\
& & $14: 1 \mathrm{U}: 17$ & 2 & 5.7 \\
& & $15: 1 \mathrm{~B}: 14$ & 1 & 2.8 \\
& & $14: 1 \mathrm{~B}: 16$ & 1 & 2.8 \\
$\mathrm{C}_{3}$ & $16: 16$ & 19 & 55.8 \\
& 34 & $15: 17$ & 9 & 26.4 \\
& & $14: 18$ & 2 & 5.8 \\
& & $15: 1 \mathrm{U}: 16$ & 3 & 8.8 \\
& & $14: 1 \mathrm{~B}: 16$ & 1 & 2.9 \\
& & $16: 16$ & 5 & 50.0 \\
& 24 & $14: 18$ & 4 & 20.8 \\
& & $13: 19$ & 3 & 16.6 \\
& & $14: 1 \mathrm{U}: 17$ & & 12.8 \\
\hline
\end{tabular}

$\mathrm{U}^{+}=$Univalent

$\mathrm{B}^{++}=$Bivalent

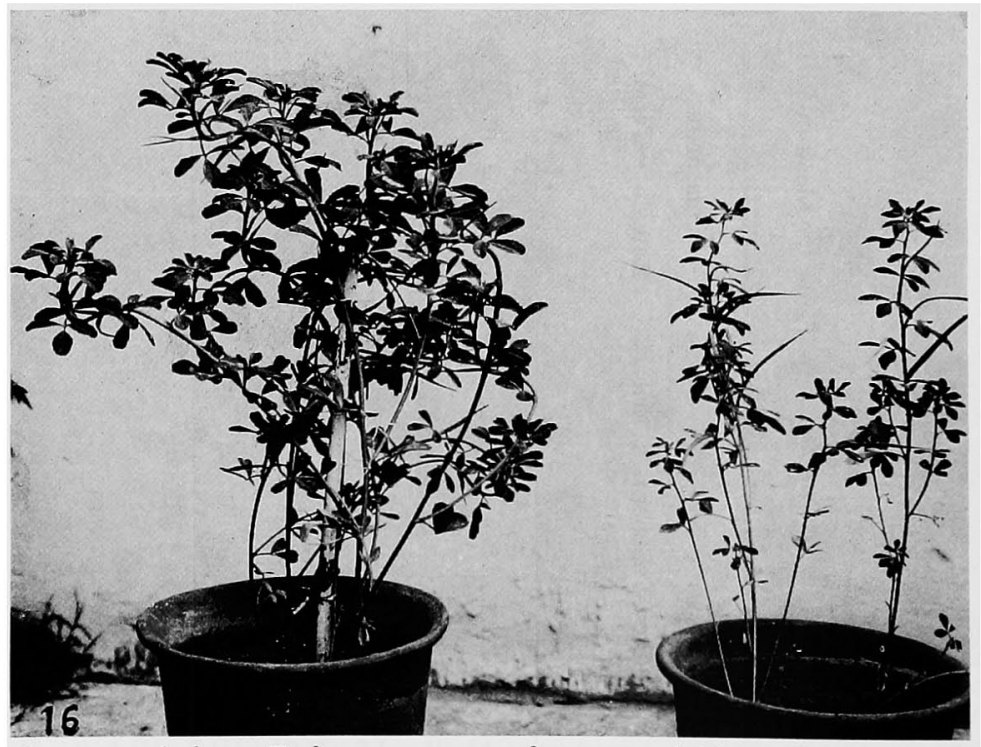

Fig. 16. Gross morphology: T. foenum graecum of autotetraploid and diploid plant (2 plants in one pot). Tetraploid $\mathrm{C}_{3}$ generation (left) and diploid (right). 
terminalization coefficient of 0.87 (Table 3). At anaphase I, 19 out of 34 cells analysed had equal (16:16) distribution of chromosomes (Table 4). The remaining cells had either unequal distribution or lagging bivalent or univalent (Table 4).

The $\mathrm{C}_{8}$ plants had shown a sharp increase in quadrivalent average, even when compared to the control $\left(C_{0}\right)$ plants (Table 3 ), while the trivalent average was further decreased to 0.21 per cell. The average number of associations was $0.71 \mathrm{IV}+0.21 \mathrm{III}+14.36 \mathrm{II}+0.70 \mathrm{I}$, range being $0-4,0-1,9-14$ and $0-2$ respectively. The chiasmata per cell ranged from 19-28 and the mean was 23.92 out which 20.96 were terminalized giving terminalization coefficient of 0.87 (Table 3). At anaphase I, 12 out of 24 cells $(50 \%)$ analysed had equal (16:16) distribution of chromosomes. The remaining cells had either 14:18 or 13:19 distribution. 3 cells showed the presence of 1 univalent lagging behind (Table 4).

Precocious disjunction of quadrivalent or bivalents or of both might have resulted in the occurrence of trivalents and univalents, which were observed in the present investigation.

Pollen stainability: A drastic reduction of pollen stainability from $92.67 \%$ in diploids to $67.10 \%$ in $\mathrm{C}_{0}$ plants was recorded. But it showed an upward trend in $\mathrm{C}_{1}(71.22 \%), \mathrm{C}_{2}$ $(76.31 \%)$ and $\mathrm{C}_{3}(79.01 \%)$ generations (Table 2$)$.

Seed set: Only 5 seeds were recovered from $C_{0}$ plant against $100-150$ seeds collected from diploid. However, in further generations the seed set/plant was considerably improved and in $\mathrm{C}_{3}$ about 80 seeds per plant were collected. The size of the seeds was bigger in autotetraploids in comparison to diploids.

\section{Discussion}

A review of earlier literature shows that successful attempts have been made to raise higher polyploids and to study their cytomorphological details in Trigonella foenum-graecum (Roy and Singh 1968, Singh and Roy 1971, Raghuvanshi and Singh 1977, Singh and Singh 1973, 1977, Singh and Jai Gopal 1979). The present work aims, not only at the production of polyploids but also to establish them in order to develop a variety which will be of improved economic value. A selected cultivar of $T$. foenum-graecum was colchicinized to synthesize an autotetraploid and it was maintained through three successive generations. A detailed cytological analysis has been carried out (Table 3, Figs. 7-15) in each generation and germplasm has been multiplied.

The present data shows (Table 1) that for successful induction of polyploidy, cotton-swab method is most suitable. It has been observed, as reported eralier by Raghuvanshi and Joshi (1965), that the seed treatment was always met with complete failure. Similar observations were made in a number of legumes by different authors (Sen and Vidyabushan 1960, Gupta and Gupta 1975, Srivastav 1983). In this case the present authors are in complete agreement with Bates (1939) and Srivastav (1983) that a check on root development and/or germination results in the failure of seed-treatment method to induce autotetraploidy. Though partial success was achieved by cotyledonary leaves immersion method, it is not much useful because percentage of success is as low as 6.25 .

The reduced growth rate and over-all development of the plants in $\mathrm{C}_{0}$ generation which appeared to gain normalcy through $\mathrm{C}_{1}, \mathrm{C}_{2}$ and $\mathrm{C}_{3}$ generations, is a common feature associated with autopolyploids and is reported in a number of plants (Chandler and Barton 1955, Zadoo et al. 1975, Raghuvanshi and Singh 1977, Srivastav 1983). The causative factors are presumed to be the reduced rate of cell division (Wettstein 1924, Eigsti 1947) and reduction in the rate of metabolic activities (Larsen 1943, Schwanitz 1951). A sharp increase in the size of stomata, both in length and breadth, is attributed to the increase in the cell size. However, in successive generations of $C_{1}, C_{2}$ and $C_{3}$ it has shown a slight decrease when compared to $C_{0}$ plants but 
still they were bigger than their putative diploids. It is generally believed that an increase in the stomatal size will result in the decrease of their number per unit area (Rao et al. 1982, Srivastav 1983). This phenomenon was observed in the present material also. The $C_{0}$ plants on average had only 4 stomata against 7 in diploids, per unit area. But, interestingly the number raised to 5 in $\mathrm{C}_{2}$ and $\mathrm{C}_{3}$ generations.

The $T$. foenum-graecum colchiploids in $\mathrm{C}_{0}$ generation have shown a pronounced gigantism which was retained up to $70 \%$ even in $\mathrm{C}_{3}$ generation. An overall enhancement of different vegetative characters viz. length and breadth of leaflet, apart from texture and colour of the leaf, must be the reason for gigantism. Such retention of gigantism by the colchiploids even in $\mathrm{C}_{3}$ generation is viewed as an advantageous phenomenon as $T$. foenum-graecum is more useful for its vegetative parts.

In case of autotetraploid plants, the basic genome is represented four times and hence it is generally expected that the chromosomal association in them should be in the form of all quadrivalents. As a result the mean number of quadrivalents per cell must be higher than any other type of associations in the cell. But in the present material, the mean number of quadrivalents is much lower than expected and bivalents outnumbered all other types of associations. The mean number of quadrivalents in $\mathrm{C}_{0}$ plants was 0.55 and range was $0-2$. Similar observations were made in variety No. 2 of Trigonella foenum-graecum (Raghuvanshi and Singh 1977), Tephrosia wallachii (Srivastav 1983) and in some cereals and grasses (Morrison and Rajhathy 1960). Some authors (Armstrong and Robertson 1956, Morrison and Rajhathy 1960) reported that plants with larger chromosomes have higher quadrivalent frequency, when raised to higher ploidy level, than the plants having smaller chromosomes. Contrary to this, Kostoff (1940) reported that plants with smaller chromosomes have a tendency to form fewer quadrivalents. The present data on $T$. foenum-graecum colchiploids supports the view forwarded by the former authors. This is because a descrete karyotypic analysis reveals that $T$. foenum-graecum has relatively larger chromosomes but only fewer quadrivalents were observed at MI of meiosis. The lower quadrivalent frequency may be due to small heterozygosity in the original material (Srivastav 1983) or localized chiasmata (Levan 1940) or genetic control (Riley and Chapman 1958, Jauhar 1975, Raghuvanshi and Singh 1977) and also the number of points of pairing initiation. In the case of present material, though a clear explanation cannot be given, it is presumed that probably a combined effect of all the above factors might have resulted in low frequency of quadrivalents. In $\mathrm{C}_{0}$ plants it is observed that the chiasma frequency per cell was always lower and never equalled to twice to that of their putative diploids. The presence of trivalents and univalents in the material (Table 3) is believed to be the reason for the drop in chiasma frequency. Similarly the terminalization coefficient (T.C.) which was 0.84 in diploids was decreased to 0.82 in $\mathrm{C}_{0}$ plants. But it has shown an upward trend in successive generations. The difference, between $\mathrm{C}_{0}$ and successive generations, in the terminalization coefficient value is believed to be more pertaining to chromosomal than genic in nature.

Despite the higher bivalent frequency and fewer quadrivalents per cell, the chromosomal distribution at $\mathrm{AI}$ was very much affected and in $\mathrm{C}_{0}$ almost $55 \%$ of the cells had unequal distribution (Table 4). However, in further generations $\left(C_{1}, C_{2}, C_{3}\right)$ more number of cells had equal distribution of chromosomes. Trivalents and univalents, though they are few in number, are much prone for misdisjunction (Srivastav 1983) and they result in the unequal distribution of chromosomes. However, despite the low mean and average of trivalents and univalents, it is not known why $\mathrm{C}_{3}$ plants had (Table 4) more number of cells with unequal distribution of chromosomes at $\mathrm{AI}$ and produced more seeds in comparison to $\mathrm{C}_{1}$ and $\mathrm{C}_{2}$.

The reduced seed set in $\mathrm{C}_{0}$ plants is believed to be the result of several meiotic errors viz. misdisjunction, unequal distribution of chromosomes at AI etc. The same reasons are expected to have influenced and decreased pollen stainability in $\mathrm{C}_{0}$ plants. 
Though the quadrivalent frequency per cell has shown a nominal increase (from 0.5 to 0.7), the sharp upward trend (from 13.77 to 14.36) in the average of bivalents per cell, from $\mathrm{C}_{0}$ to $\mathrm{C}_{3}$ is more significant feature to be noted. This type of "diploidization" in succeeding generations, observed in the present colchitetraploids, is a common phenomenon in most of the plants (Aastveit 1958, Sjodin and Ellerstrom 1969) while a case opposite to this is reported in Phlox drummondii by Raghuvanshi and Pathak 1975.

\section{Summary}

Induction of autotetraploidy has been achieved in Trigonella foenum-graecum $(2 n=16)$ by cotton-swab method using $0.15 \%$ colchicine. The synthesized colchiploids $\left(C_{0}\right)$ were maintained for three successive generations $\left(C_{1}, C_{2}, C_{3}\right)$. Detailed morphocytological analysis has been carried out in each generation. A distinct enhancement in different vegetative parts was observed in the autotetraploids making them economically more useful. The 5 seeds collected in $\mathrm{C}_{0}$ generation were multiplied and as many as 200 seeds were collected in $\mathrm{C}_{3}$ generation.

\section{Acknowledgements}

Authors are grateful to University Grants Commission, New Delhi for financial assistance.

\section{References}

Aastveit, K. 1968. Effects of combination of mutagens on mutation frequency in barley. IAEA (Vienna): 514.

Armstrong, J. M. and Robertson, R. W. 1956. Studies of colchicin-induced tetraploid of Trifolium hybridium

L. I. Cross and self-sterility and cytological observations. Can. J. Agric. Sci. 36: 256-266.

Arora, O. P. 1975. Differential response of Verbena species to colchitetraploidy. The Nucleus 18: 166-171. Bates, G. H. 1939. Polyploidy induced by colchicine and its economic possibilities. Nature 144: 315-316.

Biswas, A. K. and Bhattacharya, N. K. 1971. Induced polyploidy in legumes. I. Cyamopsis psoraloides DC. Cytologia 36: 469-479.

Blakeslee, A. F. and Avery, A. G. 1937. Methods of inducing chromosome doubling in plants by treating with colchicine. Heredity 28: 393-411.

Chandler, C. and Barton, L. V. 1955. Morphological and physiological studies of diploid and tetraploid Plantago ovata. Contrib. Boyce Thompson Inst., Plant Res. 18: 193-214.

Eigsti, O. J. 1947. The pollen tube method for making comparisons of differences in mitotic rates between diploid and tetraploid. Genetics 32: 85 .

Gupta, R. and Gupta, P. K. 1975. Induced polyploidy in Crotalaria L. I. C. juncea and C. retusa. J. Ind. Bot. Soc. 54: 175-182.

- and - 1976. Induced polyploidy in Crotalaria L. II. C. browneii and C. sericea. J. Ind. Bot. Soc. 55: 261-266.

Jalil, R., Zadoo, S. N. and Khoshoo, T. N. 1974. Colchiploid balsams. The Nucleus 17: 118-124.

Jauhar, P. P. 1975. Genetic control of diploid like meiosis in hexaploid tall fescue. Nature 25: 595-597. Kostoff, D. 1940. The frequency of cell divisions in polyploid plants. Curr. Sci. 9: 217-228.

Larsen, P. 1943. The aspects of polyploidy in the genus Solanum Kgl. Danske Videnskal. Selskab. Biol. Medd. 18: $1-51$.

Levan, A. 1940. Meiosis in Allium porrum, a tetraploid species with chiasma localization. Hereditas 26: 359394.

Morrison, J. W. and Rajhathy, T. 1960. Chromosome behaviour in autotetraploid cereals and grasses. Chromosoma 11: 297-309.

Raghuvanshi, S. S. and Joshi, S. 1965. Studies on the comparative effects of certain chemicals on the polyploidising efficiency of colchicine in Trigonella foenum-graecum L. Caryologia 18: 69-84.

- and Pathak, C. S. 1975. Polyploid breeding and possibility of raising double varieties in Phlox drummondii Hook. Cytologia 40: 355-363. 
- and Singh, A. K. 1977. Polyploid breeding in Trigonella foenum-graecum L. Cytologia 42: 5-19.

Rao, S. R., Raina, S. N. and Srivastav, P. K. 1982. Induced autotetraploidy in Phlox drummondii Hook. J. Cytol. \& Genet. 17: 49-54.

Riley, R. and Chapman, V. 1958. Genetic control of cytologically diploid behaviour of hexaploid wheat. Nature 182: 713-715.

Roy, R.P. and Singh, A. 1968. Cytomorphological studies on the colchicine induced tetraploid Trigonella foenum-graecum L. Genet. Iberica. 20: 37-54.

Schwanitz, F. 1951. Untersuchungen an polyploiden Pflanzen XI. Zur Chlorophyllgehalt der diploiden und polypoloiden Pflanzen. Züchter 21: 30-36.

Sen, N. K. and Chedda, H. R. 1958 . Colchicine induced tetraploids of five varieties of black gram. Ind. J. Genet. 18: 238-248.

- and Vidyabhusan, R. V. 1960. Studies of the induced polyploidy in horse gram. Ind. J. Genet. 20:212-233.

Singh, A. and Gopal, J. 1979. Higher polyploids in Trigonella foenum-graecum. Cytologia 44: 661-667.

- and Roy, R. P. 1971. Studies on the colchiploid of four species of Trigonella. Cytologia 36: 133-142.

- and Singh, D. 1973. Meiotic study of an autotetraploid Trigonella foenum-graecum. C. I. S. 14: 12-14.

Singh, D. and Singh, A. 1977. Meiotic behaviour of autotetraploids of Trigonella foenum-graecum. Genet. Agr. 31: 53-68.

Sjodin, J. and Ellerstrom, S. 1969. Note on some diploid and tetraploid hybrids in the genus Secale. Hereditas 62: 433-437.

Srivastav, P. K. 1983. Cytogenetics of Tephrosia and Crotalaria. Ph. D. Thesis, University of Jodhpur, Jodhpur.

- and Raina, S. N. 1981. Cytogenetics of Tephrosia. I. On the differential chromosome pairing in colchiploid stock of $T$. wallichii. Cytologia 46: 89-97.

- and - 1982. Cytogenetics of Crotalaria. I. Induced autotetraploidy in C. termatea. Cytologia 47: 99.

Wettstein, F. V. 1924. Morphologie und Physiologie des Formwechesls der Moose auf genetischer Grundlage. Z. Ind. Abstammg. u. Vererbgslre. 33: 1-236.

Zadoo, S. N., Roy, R. P. and Khoshoo, T. N. 1975. Cytogenetics of cultivated Bougainvilleas V. Induced tetraploidy and restoration of fertility in sterile cultivers. Euphytica 24: 517-524. 